\title{
Craft and Design in an Age of Climate Crisis
}

Feature Interview 7.1. Laura McCusker, Furniture Maker, Established Maker (Interviewed February 2016)

It took me a while to really get an idea of what's been going on here in Tasmania on the ground. When I turned up, I was just really observant and I listened a lot, because there's obviously a huge history down here of environmental ethics and the importance of the environment and the timbers and the materials. And I was very conscious of just watching and listening and being aware of what was happening for a good few years. [ ... ] When I was in Sydney we used to pay a premium for Tasmanian oak and when I moved down here I noticed the people down here use Tasmanian oak as a building product or as firewood or fence palings. It really was a super-undervalued resource. [Instead] it was all about Huon Pine, myrtle, sassafras, celery top, all of these other timbers. And because I didn't have a really good understanding or I was very wary of the environmental, of the politics that comes with those timbers-where they were from, how they were sourced, was it ethically sourced, was it the right thing?-I basically just took a big step back and said I don't know enough and I'm not confident that I know where it's come from.

(continued)

(C) The Author(s) 2020

S. Luckman, J. Andrew, Craftspeople and Designer Makers in the

Contemporary Creative Economy, Creative Working Lives, https://doi.org/10.1007/978-3-030-44979-7_7 


\section{(continued)}

And then they locked up a lot of those timbers, and so the timbers that you could get, you were getting them from people who took them out; there are some cowboys out there that you don't know how and where they got the timber. So from an ethical point of view it's a little bit dodgy, but then also from a very practical point of view, if a timber hasn't been properly seasoned and air-dried and kiln-dried you can end up paying money for timber that's not going to work or isn't very good. So, from a consistency of pricing and product and quality and the ethics of it, I basically just said: "Okay, it's Tas oak. That's what we're working with and that's all we're working with." And we developed a number of different ways of using Tas oak that, I mean I've really enjoyed it. We've developed a way of triggering the tannin in the Tas oak to make it go black by mixing up a combination of steel wool and vinegar and then spraying it on and it comes up this beautiful black colour. We've been working with soap finishes which are traditional finish of European lighter timbers and that triggers the colour. It takes all the pink out of the Tas oak and it almost goes this sort of, it's almost this kind of cool olive green kind of colour, more like spotted gum, that's really beautiful. So there's ways of actually handling Tas oak that makes it, elevates it. And even just calling it Tas oak is the equivalent of calling a porterhouse steak 'meat'. It's just this generic term that covers about five different eucalypt species and they just call it "Tas oak". I mean it's Eucalyptus regnans, Eucalyptus obliqua, [Eucalyptus] delegatensis. They're the Latin names, but it's stringy bark or mountain ash, all of these names are really evocative and beautiful and totally - and even just calling it the right name or the local colloquial name elevates it to another level. [ ... ] Pretty much all of the timber we work with is Tas oak. There have been a couple of occasions we've made some stuff out of Huon Pine but that's actually when people have come to us with their own stack, which has been really, again a really nice opportunity. (Laura McCusker, furniture maker, established maker, February 2016)

In an age of climate crisis and too much 'stuff', it may seem a little strange to be talking about craft-based solutions to waste and the eco-impacts of making. Craft itself is already a big field, but it is also currently overattenuated through constant evocation of the idea of 'craft', 'crafted' and 'craftsperson' as part of wider consumer and cultural trends around the 
artisanal. 'Craft', too, is both a noun and a verb and 'crafty' an adjective. Accordingly, 'craft' today is an incredibly loaded term, just as likely to be evoked dismissively in reference to the incredible amounts of tat currently globally available and most famously mocked on the now (mercifully) defunct website that gave rise to the hashtag \#regretsy. The focus of 'regretsy' was to shame pointless, embarrassing or just poorly executed amateur-made objects representing both a perceived waste of time and, importantly in this day and age, material resources. Regretsy was living proof that 'just because you can, doesn't mean you should.' But it is also important to acknowledge that the internet world of craft is just the most recent iteration of a much longer history of crafting with its deep, millennia-old knowledges of materials and processes. Contemporary craft practice can also offer insights into useful everyday material practices that mitigate the amount of waste humans generate. Thus a key tension at the heart of artisanal capitalism that revealed itself in our study is the desire on the part of many makers to work ethically as well as generate an income, all the while questioning: 'does the world really need more "stuff"?' This chapter explores how makers are working to negotiate these tensions and seeking to become part of the solution, not the problem.

A central tenet of craft practice has long been a profound respect for materials, a valuing that includes reuse, and this sensibility continues to inform much craft practice today. So too do ideas of workmanship, quality and building to last, which also have rich and long traditions in craft practice and are all the more salient in the age of 'fast fashion' and accelerating disposability. Writing on the cusp of the second Western craft revival in the 1970s, which was informed by a 'back to basics' sensibility and emerging environmental awareness, leading British architect, industrial designer and craftsman David Pye (1995), observed in his iconic book on craft and making, The Nature and Art of Workmanship:

The traditional association between high regulation and durability, whether true or false, has no force any longer. The highly regulated ball-point pen with which I am writing will be thrown away next week.

We have already remarked that traditional ideas of workmanship originated when man-made things were few and highly prized, of whatever sort they were, and when highly regulated workmanship must have been so rare as to seem wonderful. But now things are all too many, high regulation is 
commonplace, and free workmanship as such is fast dying out, and high regulation, of all things, is least respected. Consider any scrapheap. (83)

Evoking one of the leading thinkers of the earlier Arts and Crafts Movement that was influential across much of the Global North, not coincidentally in the wake of the Industrial Revolution, Pye (1995) continues:

Ruskin said 'If we build, let us think that we build forever.' Shall we say 'If we build, let us remember to build for the scrapheap'? Shall we make everything so that it goes wrong or breaks pretty quickly? I think not. Men do not live by economics alone. There is a question of morale involved. A world in which everything was ephemeral would not be worth working for. There are overwhelming social and aesthetic arguments for durability in certain things even if, as we are told, there are no economic ones. (83)

Such an ethos certainly resonated with the 1960s and 1970s counterculture and, with it, the last major wave of mainstream interest in craft. Craft practice has come a long way since the now clichéd 1970s brown ceramic mug and macramé pot hanger (though the latter at least is currently experiencing something of a revival), but the sense of craft as a practice with the potential to live and make in greater harmony with the environment persists.

Today we can see ways in which craft materials and practices embody a tangible sense of what American political theorist and philosopher Jane Bennett (2001) calls 'enchantment':

Enchantment is a feeling of being connected in an affirmative way to existence; it is to be under the momentary impression that the natural and cultural worlds offer gifts and, in so doing, remind us that it is good to be alive. (156)

Such a relationship to natural resources and skilled processes parallels that felt by many makers and craftspeople. For them, materials (e.g. rock, metal, clay, wood, glass, fibre) are to be worked with, not upon. The knots of the wood or the feel of the clay represents the material's own more than human agency in the making process. This deep haptic knowledge, embodied tacitly by craftspeople, is something Bennett (2010) acknowledged more recently: 
What woodworkers and metallurgists know quite well: there exist 'variable intensive affects' and 'incipient qualities' of matter that 'external forms [can only] bring out and facilitate.' Instead of a formative power detachable from matter, artisans (and mechanics, cooks, builders, cleaners, and anyone else intimate with things) encounter a creative materiality with incipient tendencies and propensities, which are variably enacted depending on the other forces, affects, or bodies with which they come into close contact. (56)

It is in this way that issues of sustainability, minimising one's environmental footprint (including energy use and lifestyle generally) and being crafty with materials sourcing and reuse emerged consistently in our interviews with makers, the majority of whom were engaged either explicitly or implicitly with issues connected to a concern for the environment, waste and consumption. Although only one of our interview questions focuses on this, it was clear that for many of our participants contemporary environmental or social agendas provide a strong motivation and framework for professional practice (see also Schwarz and Yair 2010).

This was certainly the case for jeweller Clare Poppi of Small Green Leaf, whose general approach is not atypical. Her practice as a jeweller is based around sustainability. She is influenced by the activist-researcher approach of Kate Fletcher $(2014,2016)$ and discussions around makers not just designing in an ethical manner but also considering how, once an object is no longer wanted, it can be broken down into parts for reuse or recycling - jewellery as part of a circular economy. For this reason, she is also interested in the discussion around repurposing, recycling, fixing and maintaining items. These ideas inform the manner in which she makes jewellery. She is also concerned with the ethical sourcing of metals, including fair-trade sourcing, so she works with local fossickers who find and cut their own stones. This way she knows that they did not exploit others in sourcing their gems. In her studio she has tried to minimise the use of chemicals, for which jewellery production is notorious, and is always seeking solutions that are less damaging to the environment. Finally, she is glad to be a jeweller working with precious metals because such expensive items are unlikely to be simply thrown away:

Even just thinking about the value thing, with metals I as a jeweller predominantly will work with precious metals, whereas a lot of other jewellers may work with plastics and found materials and things, which is fine. But I like the idea that because that is so inherently precious, that material, people 
won't throw it away. [... ] It can just so easily be recycled and melted down. They can bring it back to me to do that or they can take it to somebody else, and people tend to hang onto it for that reason, that they have a perceived value attached to that. (Clare Poppi, jeweller, established maker, September 2016)

But while Clare's practice might be at the more deliberate and systemic end of the climate crisis-motivated attention-making spectrum, hers is hardly a unique commitment.

As materials specialists, many makers are drawn to working creatively to develop more sustainable modes of production and materials use. Indeed, looking across the whole project-not just the interviews but also the online searches undertaken to identify potential interviewees-we identified five different but often overlapping ways in which Australian craftspeople and designer makers sought to lessen the impact of their practice upon the environment:

1. Materials sourcing:

(a) Use of sustainable energy sources and materials

(b) Up-/recycling

(c) Whole-of-animal use (e.g. leathers, bones, feathers and other by-products of the meat industry)

2. Craft $=$ quality $=$ made to last $/$ made to hold onto $/$ made to be repairable

3. Craft as part of a lifestyle downshifting choice

4. Low carbon futures and digital tools-seeking new ways to minimise waste through making/designing to order

5. Circular economies of craft

\section{Materials Sourcing}

The aspect of making around which the people interviewed in this project were most likely to express environmental concerns and awareness was in their sourcing of raw materials. This was especially the case for those working directly with natural materials such as timber, leather and fibres, though-interestingly - less so clay. Indeed the very choice to use natural materials rather than synthetic ones is often itself an environmental choice 
and preference. Such an appreciation for the provenance of materials is perhaps unsurprising given their centrality to the practice of making. But importantly, and practically, it is also a key site for negotiations and tradeoffs for makers between what is possible (what they can afford and access and what that particular material might be able to actually do, the final item's price point, the time available to them to search out alternatives and their own ethical belief systems) and what is not.

It is in care in sourcing materials that many makers most explicitly locate their making ethics. This particular manifestation of an attentiveness to the wider impacts of their making, especially as it impacts upon the natural world, is one important way in which contemporary craftspeople and designer makers seek to work with the affordances of resources as part of an affective, ethical relationship with their materials. We can see here again resonances of what Jane Bennett (2010) identifies as the vibrant materiality of non-human objects, which in this instance can offer an engagement of enchantment as the basis for moral action:

For me the question is not whether disenchantment is a regrettable or a progressive historical development. It is, rather, whether the very characterization of the world as disenchanted ignores and then discourages affective attachment to that world. The question is important because the mood of enchantment may be valuable for ethical life. (Bennett 2001,3)

Caring about where things come from and whether this is sustainable and considering whether the maker's use of them justifies the act of creative destruction they are about to enact upon the materials in their current forms are in this context all-important questions to ask as part of making ethics. Makers in this study employed a number of sourcing strategies to enact this care.

\section{Use of Sustainable Materials: Sourcing Timber}

An important concern about materials sourcing facing many of the makers we interviewed, again especially those working with natural materials, was seeking out sustainably sourced raw materials. This was most marked in those makers working with timber. Timber in Australia, as elsewhere, is a craft resource with a high-profile public history of protest and contention. For decades, protestors have rallied against the further logging of Australia's old-growth forests, already monumentally depleted by just over 
200 years of European settlement. Agroforestry of both native and introduced timbers has been introduced, but by and large this has not focused on the artisanal production of fine furniture and household and personal items, and thus the supply chains and tree species involved are not always suited to this market. It is this larger context that operates as a backdrop to the challenges of sourcing timber that is at once workable and beautiful but also sustainable. 'Sustainable' here is a reference to maker and market desires for items that are made from ethically sourced timber, as well as a reliable supply chain for the maker. For, although one-off pieces are often produced, especially on commissions or as gallery pieces, from unique sources of timber (sometimes from literal as well as figurative windfalls), makers generally require some regularity in materials sourcing to ensure the sustainability of their own business.

Because Tasmania's recent history of quality furniture handmaking is a direct result of proximity to quality timbers (including the highly prized but increasingly endangered Huon Pine), Tasmanian makers were particularly attentive to the challenges of ethical timber sourcing. For Laura McCusker (see Feature Interview 6.1), coming to Tasmania, famous for its forests and their timbers but also for the battles over them, the issue of the provenance of material cannot be ignored. In Tasmania, many of these debates are galvanised around the status and desirability of the timber know as Huon Pine or Lagarostrobos franklinii. Unique to the forest of south-west Tasmania, the fine-grained and warmly coloured Huon Pine is now increasingly threatened as the result of logging and habitat loss. A victim of its own success, initially, the timber was harvested aggressively for boat building, for which it is particularly well suited as its natural oils resist rotting. More recently, it has attained an iconic status, partly as a result of its relative rarity, and all sorts of smaller household items made of the timber are plentifully available, largely to the state's growing visitor market.

This capitalising upon the mystique of the timber through the churning out of what many see as largely cheap tourist trinkets was generally looked down upon by the makers we interviewed:

I think that there are a lot of good practitioners that do use specialty timbers, but sometimes I think specialty timbers can be misapplied in their use. So, for example, I think boat building with some of the specialty timbers is what they're designed-well not designed for, but you know, what they're specifically really well suited for. But sometimes when you see like hundreds 
of chopping boards [made] out of Huon Pine, and boat grade Huon Pine, you just kind of go, "Oh God what's going on here", like. And so, it's being sold because its Huon Pine, but the thing is, often some people, if you show them a piece of Huon Pine, then show them a piece of radiata and macrocarpa, they wouldn't necessarily know the difference. And even though they've both got very different properties in terms of manufacturing-making and appearance-it's just like it's a branding thing that [makes] people [ ...] go for those things [made of Huon Pine]. So I'm not necessarily opposed, categorically, to people being able to use those timbers, I just think that the application should be limited to certain applications, or people should really think about what they're using them for and if they're using it responsibly. So either like very personal detailing in a cabinet or something, or reserved for [detail] work, or reserved for boat work, because a lot of those timbers take forever to grow, and [ ... ] they've got resistance, so they're perfect for boats. [ ... So] if you're using those timbers that are like really, really fine grade timbers and they've been turned into slabs of chopping board, or pepper grinders, or fruit, or something, $[\ldots]$ that same thing could be made out of a fast growing timber and still sell, then maybe that's something to consider. But if it wouldn't sell out of that other timber, like that's maybe a little bit of a judgement thing, but like why should it exist? (Male, furniture and lighting designer maker, established maker, February 2016)

It is in this context where Huon Pine is fetishised, that working with 'Tassie Oak' (which is actually not a single species but rather a range of local Tasmanian eucalypt timbers) and rendering it fashionable or at least desirable to a discerning market becomes a deliberate and calculated act of bringing the consumer market into a more sustainable relationship with the goods they buy:

All the timber [I use] is from responsibly managed sources, $[\ldots$ ] it's not a difficult thing to do, to ensure that your timber is from those sorts of sources. [ ... ] In terms of actually working with timber, [Tassie Oak is] not the easiest, [but] it's not bad. But machining and what not it's kind of like it's okay. I like it because it's local and it's easy to get a hold of, it's cheap comparatively to other speciality timbers. And I think there's an opportunity to-I'm sure other Tassie people might say this as well, that you talk tothere's an opportunity to elevate its status a little bit. It's probably seen as a lower grade timber commercially. But I think you can, as a designer, you can change perceived values of things, materials, and I think using Tas oak is a good opportunity to do that, because it's a great resource and if we can 
promote [it] through good design then that's a really healthy thing. (Scott van Tuil, furniture maker and designer, emerging maker, February 2016)

We also encountered some unlikely but illustrative examples of what can be possible at the intersection of desirability, technology and opportunity. During the course of our project, a new means of accessing Huon Pine and other rare rainforest timbers emerged. One of the reasons for the high profile of debates around timber sustainability that are particularly notable in Tasmania was the hard-thought, high-profile and ultimately successful protest blockades against the Gordon-below-Franklin Dam in the forests of south-west Tasmania in 1982-1983. The government's intention was to extend the state's hydroelectricity supply. The blockade and wider campaign to get UNESCO World Heritage status for the area is seen largely as a formative moment for the Australian Greens. In 1986, the Pieman River on the west coast was dammed, creating Lake Pieman and drowning what remained of the local forest. Recently, Hydrowood (n.d.) - the 'world's first underwater forestry operation'-has begun harvesting these rare timbers and drying them under controlled conditions. Recognising the specialist market for such wood on this significant but not inexhaustible scale, they are focusing on craftspeople and master builders as a primary market because of the uniqueness and qualities of the timber:

This is real wood. Solid timber that comes untouched and intact.

Wood that craftsmen and master builders dream of working with. Wood with a story to tell, a character like no other and in quantities thought never to be seen again. (Hydrowood n.d.)

As they go on to note, it is rare for this kind of timber to be available today as large intact logs rather than salvaged smaller pieces. In marketing storytelling that aligns perfectly with that of the crafts community, the undoubtably 'unique story' of this timber is emphasised. We became aware of Hydrowood in 2016 when references to how they were sourcing timber began appearing in our interviews. Contact had been made with local craftspeople and designer makers:

But recently, maybe three weeks ago, this guy from Hydrowood came to visit. They've got the licence to go to Lake Pieman, which is one of the lakes that hydro [hydro-electric power plant] flooded, and pull out some of the trees that are standing there. And so there is a way to get some of those 
timbers, which we know is ethical and they've been properly kiln dried and the timber is really stable. [ . . ] ] The dam is up to 30-40 metres deep in some areas so they know that these trees are huge, and they've been dead for 30 years so they're actually-they've realised that it's really well seasoned. There have been other lakes down here where they've been able to pull up Huon Pine from the bottom of the lake and it was a felled tree. And because of Huon's high resin and wax contents, it doesn't get waterlogged. So they were able to pull up the logs and they've been fine. But what's interesting about this is because the roots are still in the ground and the tops are above the water it hasn't sucked any of the water up. It hasn't become waterlogged. It's actually really well seasoned. It's been dead for 30 years and then when they're cutting it down and opening it up it's really stable. So it's an interesting way, and the scale of what they're getting, [there is] myrtle and blackwood. So the bark and the sap would sort of protect the internal, the hard wood, the heart wood. (Laura McCusker, furniture maker, established maker, February 2016)

The desire to source timber sustainably is hardly unique to Tasmanian makers, but it certainly is a concern built into that maker ecology, including its commercial supply chains. For reasons of space we cannot do justice to all the examples of timber sourcing attentiveness we encountered across the country. But in focusing on how this aspect of obtaining materials is playing out as a local making ecology in Tasmania, we seek to capture some of the breadth of what is possible and the important role of makers as conveyors of meaning and value in the consumer marketplace.

\section{Negotiating, Sourcing and Using Animal-Based Materials}

Arguably the most overtly politically fraught aspect of making we encountered concerned the use of animal parts. Obviously, working with wool does not require the death of the animal, but making using of bone material, skins, fur and leather does. We encountered very few makers working with the first three items. Those who were tended to be making one-off pieces using materials sourced from second-hand markets and opportunity shops (e.g. fur and skins); they were reusing materials already well and truly in circulation and previously rendered 'waste'. Similarly, those whose work drew upon raw materials such as bone often were drawn to these byproducts of the meat industry through a desire to turn them from 'waste' to use. Such an approach, which many may find ethically or aesthetically upsetting, was for many others part of an ethics of environmentally 
sustainable making. A sense of the importance of using the whole animal permeates discussions with makers working with these materials, connecting their craft practice with contemporary international trends around food and the revaluing of offal and not just prime, choice cuts. For millennia, people have worked with the material affordances of the animals around them. In the Australian context, finding a use for the whole slaughtered animal or as much of it as possible connects this kind of making to the ongoing practices of traditional Aboriginal and Torres Strait Islander living and making, offering insights into how on a small scale we can live more in tune with the natural environment.

Although small-scale making practices may be understood more easily within this kind of ethics, it is when things become industrialised on a much larger, global scale that the situation gets much more complex, and this is certainly the case with leather. Leather is a material with a long, deep and rich history in making, but it is also a material notoriously polluting to process. Historically, tanning has been a substantial contributor to the contamination of waterways in both urban and rural contexts. Today, the challenges of working with this important, durable and attractive material require ongoing negotiation on how best to minimise the impacts. Surprisingly given Australia's substantial beef industry, the country produces many skins but has limited leather production. Most tanning, even of Australian hides, is undertaken overseas introducing a whole series of negotiations around cost, travel miles, quality of product and environmental and worker protections for the Australian craftspeople and designer makers sourcing this material:

There's a lot of energy in any type of leather, and it is something certainly that I think about. I mean in shoes and boots I use more kangaroo really than anything, and that's for a whole lot of reasons but certainly ecological and environmental reasons come into that, it's as local a leather as I can get. Australia doesn't, unfortunately produce any high-quality leather once you step away from kangaroo. [ ... ] There are a couple of smallish tanneries in Australia, but for someone like me where 80 per cent of the cost of my product is my labour, you really need high-quality material. [ ... ] So I really do shop around the world, I tend to use really only vegetable tan leathers, which is a much less toxic kind of form of tanning. [ ... ] And the quality leathers come from countries like America, Italy, the UK where there are environmental regulations and safeguards in place. [ ... ] But as for the Australian beef hides, I mean some do get tanned here but a lot go offshore in a pickled state, and then the tanning happens overseas. And for the really 
high-quality kangaroo it's tanned in Germany, it's not tanned, I mean kangaroo is tanned in Australia and you can get [it], I mean it's an excellent leather, you can get great kangaroo that is Australian, that's what I use, but you know the premium grade stuff is tanned in Europe. (James B. Young, shoemaker and outfitter, established maker, October 2015)

Well I love the fact [kangaroo leather is] relatively local and it's here in Australia and I know it hasn't come in from China and who knows what they've done to it. I'd love to be using more ecological leathers and they're quite expensive and so for classes and where I might buy the odd skin in for a particular job, I'm just getting what I can get because it's just so hard, there's only really one or well there's two places I use for leather. One's in Sydney, the other one is in Queensland, north of Brisbane. [ ... ] What I need here is a range of different colours and styles of shoe, [when] people come here they want, some want rustic leathers and some want really highend looking shoes that are very fine leather, so I've got a real combination $[\ldots]$ from one end to the other really. (Luna Newby, shoemaker, established maker, February 2017)

James and Luna represent here a number of the approaches regularly taken by the makers we spoke to when seeking to minimise the environmental impacts of working with leather. Paying extra to get leathers that are processed in Europe rather than China, the former with its much stronger protective policy frameworks, was a crucial one. So too was seeking out leathers coloured using natural, vegetable dyes. The foregrounding of kangaroo leather points to another way in which makers sought to minimise the environmental footprint-literally-of their leather use, albeit in terms of its impact upon the environment while the animal is alive. As an animal native to Australia (unlike all bovines and other hardhoofed farm animals), soft-footed kangaroos leave less of an ecological footprint than farmed animals, whose hard feet churn up soil, making it more prone to erosion and the introduction of weeds.

Another approach often taken by makers working with leather was to source offcuts, end-of-run or remaindered pieces:

I use repurposed leather, which also makes it very unique. As far as I know there is only one person in Canada and one person in America using repurposed leather. [ ... ] I started getting offcuts from upholsters and also op shops buying up leather jackets and then sort of let myself believe that I could find full hides, that it was possible, and found in Melbourne- - there's a lot of resources in Melbourne. [I] got onto people who had hides that had 
just been sitting around for a really long time and they didn't want them, so I was able to buy them up and that's why you see a lot of leather behind you. And so it's not just about taking old things and using them like I'm using brand new old things, it's more about the ethos that there is so much waste out there and everything I am using was just going to be landfill at some point, because I am choosing to look further and to use the resources that we have already got rather than just consuming more and more. [ ... ] It means I don't have the instant success that a lot of people do when they're buying on-trend leather, like they will get the swatches and they will say, "What do you want?" and people will go metallic gold and dusty pink, and I can't offer that so my market is definitely much more specialised and is more for the people that are appreciating what I'm doing. [ ... ] So I'm doing soft-sole shoes for kiddies and I've just started doing adult sizes as well. [ ... ] The reason I started with kiddy shoes instead of with adults is because I didn't have a viable source for repurposed leather for adult shoes, because obviously you need a lot more-it needs to be bigger pieces to be stronger and there is certain technical requirements that aren't so relevant for a kiddy shoe or are a lot easier to get around. (Female, shoemaker, emerging maker, October 2015)

As this shoemaker makes evident, such an approach can provide interesting variety but is difficult to depend upon as a reliable and consistent supply chain. The same challenge faces the many other makers who deliberately choose to work with found, second-hand and other recycled materials.

\section{Up-/Recycling}

At the moment all of my products are made from hardwood. And my decision was to use recycled hardwood because that resource is available, and I don't want to see it go to waste as buildings are demolished or wharves ripped up. [ ... ] It takes a bit more consideration to make sure you exclude pieces that have splinters or chips or cracks or any things like that, you'd have some of that in virgin timber anyway. [ ... ] It's a really key part of why I'm doing what I'm doing, and it kind of drives a lot of my decisions. (Corner Block Studio, picture frames, emerging maker, September 2016)

Across a wide range of practices, the materials-sourcing strategy our participants noted most frequently as the way they seek to reduce the environmental impact of their work was materials up-/recycling and repurposing. Indeed, many crafts have deeply embedded practices of materials 
recycling and reuse, motivated by a respect for the ongoing value of the material. Many of these practices are considered common sense rather than anything worthy of comment or recognition. Some are so entrenched they have their own terminology - for example, jewellers' use of 'lemel'. This story of lemel comes not from one of our research participants, but in an email from our project team member Belinda Powles, herself a trained jeweller, expressing her surprise at the absence of a discussion of metal reuse by the jewellers with whom we had spoken. In her words:

Most jewellers have a specially designed workbench which has a half circle cut out and either a leather canopy or wooden tray to catch all the filings and small offcuts of precious metals. [ ... ] These filings are the sawdust of the jeweller's world and are called lemel. Each time a jeweller changes the metal they are working with they shake these filings into a jar called a lemel jar-so you would have one [each] for fine silver, sterling silver, 9-carat gold, 18-carat gold, platinum etc. This material is low grade because it can contain solder and other contaminants. When these jars are full they are sent to a refiner to be cleaned and separated back to their metal elements and returned to the maker as new stock material, or the refiner can also purchase the material at the price of the metal set that day. If you were using a base metal such as copper or brass the same process would be followed - not because of the value of the metal but because these metals would contaminate the precious metals by reducing their alloy.

Jewellers also collect clean stock materials, for example small scraps of sheet material, rod or tube. These large pieces are also collected but are cleaner lemel and thus of a higher grade. At Art School we were taught how to ingot this material by running a magnet over it to remove any iron from filings or saw blades. We would then melt the metal in a crucible with borax to clean it and cast it into an ingot mould or for gold (which was often a smaller amount) we would carve a small depression into a charcoal block to form a small nugget. This metal would then be pickled (cleaned in acid), forged and rolled either into sheet or wire to make into the next piece.

I have noticed that many jewellers on their website have listed that they use recycled materials. It is funny-I had not really thought about it in the context of recycling/being green. For me it was economy - the materials I used were so expensive they had to be collected and reused because it was just too expensive not to, but I like the new lens through which this is seen. (Belinda Powles, pers. comm., 23 August 2016) 
Only two of the jewellers we spoke with mentioned this in interviews when we asked about how they paid attention to the environmental impact in their practice:

A lot of people don't mention this, because it's just a given, but all the silver I use is recycled. It comes from a factory where it's gone through-it's been something else in a past life. Or the gold, if I've used gold, you know, there's only so much in the world, so it's possible that the gold I've used has come from Egypt, way back, you know, it's not going directly to the ground and digging it up. (Female, contemporary jewellery, established maker, February 2017)

Such re-circulation of precious metal is also possible on a hyperlocal level:

I've tested the water there and done some market research by being at the market and chatting to people and people are looking for someone like me who can recycle their old gold chains and turn them into bangles [with] that personal touch, when it comes to experiencing something that someone else made by hand and it was made from old stuff, that they didn't have to go and buy any materials. (Kate Hunter Designs, jeweller, established maker, November 2015)

Jewellery making, as indicated above in the opening discussion of Clare Poppi's alternative sourcing practice, is also notably connected to the international flow of not just precious metals but also precious stones, with all the histories of mistreatment of people and place that accompany it. For this reason, many jewellers we spoke with were committed to practices that actively sought to disconnect their making from all forms of exploitation:

I'm a founding member of this group called the Ethical Makers Movement. We're very new, and we're just putting it on the table the fact that we're making objects to be consumed and we're contributing to this whole capitalist society, and we want to do things better. Mining's a real issue and lots of jewellers aren't addressing that. You ask people, "Well how do you feel about using diamonds?" They just don't want to answer that question. So there's a lot of passion behind where materials come from, I think certainly amongst some of the jewellers and [they're] wanting to start to talk about it. (Vicki Mason, jeweller, established maker, April 2016)

But it is not just jewellers who are concerned about the environmental impact of their sourcing strategies. 
The revalorisation of waste through, for example, the use of offcuts, industrial leftovers, opportunity shops and other second-hand goods was a recurrent theme across many of the interviews. Using 'waste' or excess, as we have already noted, is not necessarily a reliable business strategy for all makers; it does not tend to facilitate consistency of outputs or indeed a stable supply of materials. But it is worth also highlighting that for some makers waste does indeed provide a reliable means of running an economically sustainable business; some unwanted excess, such as used bike tyres and empty glass bottles, can be relied upon. For example, each year the UCI World Tour-accredited Tour Down Under not only brings worldclass cycling to Adelaide, Australia, but it also churns through a lot of first-rate rubber. Like many of the makers we interviewed, BUCK!T Belts, who turn used bike tyres into belts, wallets and other everyday accessories, are passionate about finding ways to make a living while also minimising the impact of their production practices (see Figs. 7.1, 7.2, 7.3 and 7.4). Similarly, in her glass bead making, Julie Frahm works with glass from a number of sources, including glass that is routinely discarded:

So my use of recycled glass was deliberate. I did start [my current practice] when the global financial crisis was on; the world was just ridiculous, no one knew what was going to happen, $[\ldots]$ it was just at a time when I questioned a lot of things in my life. 'What do I want to do that's different? What do I want to do that's important?' Those big sorts of questions, 'What am going to do in my practise that's different from other people?' So I came up with this idea and it was Depression glass. [ ... ] The exhibition was at Lustre Galleries and it really worked, it really resonated, people loved it; a lot of the work sold. I thought hey cool, this is cool and it was really simple, it was the first time I'd used recycled glass but it really—people really liked it, so it's just been a part of my practice since then. [ ... ] So I've learned a lot over that time in terms of recycled glass. [ ... ] So you can't just use any type of glass, you sort of have to be quite respectful of the glass as well so you don't colour it too much, you don't want to change it too much, you need to keep it quite pure in a sense. (Julie Frahm, glass bead artist, established maker, May 2016)

In addition to working with the Depression glass, which is still easily found second-hand, Julie capitalises on the everyday excess of richly coloured glass generated through contemporary everyday consumption: the light blue of Bombay Sapphire gin, the dark blue of Skyy Vodka, the greens of wine and even the ambers of beer-all can be and are reworked into handcrafted lampworked beads. (See Figs. 7.5, 7.6, 7.7 and 7.8.) 

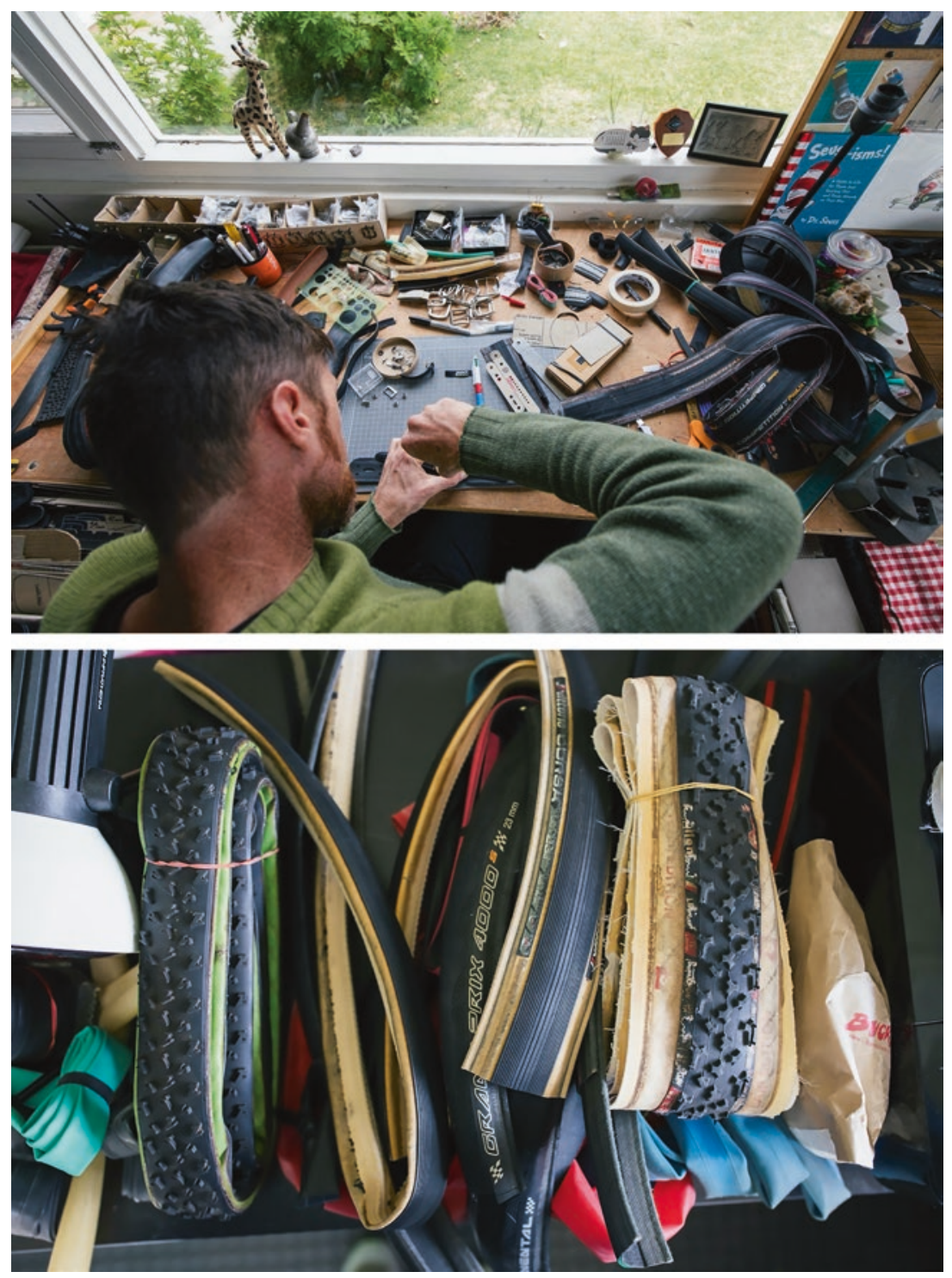

Figs. 7.1-7.4 BUCK!T Belts (and accessories) maker Craig in his workshop turning used bike tyres into products for sale. (Photographs: Rosina Possingham Photography) 

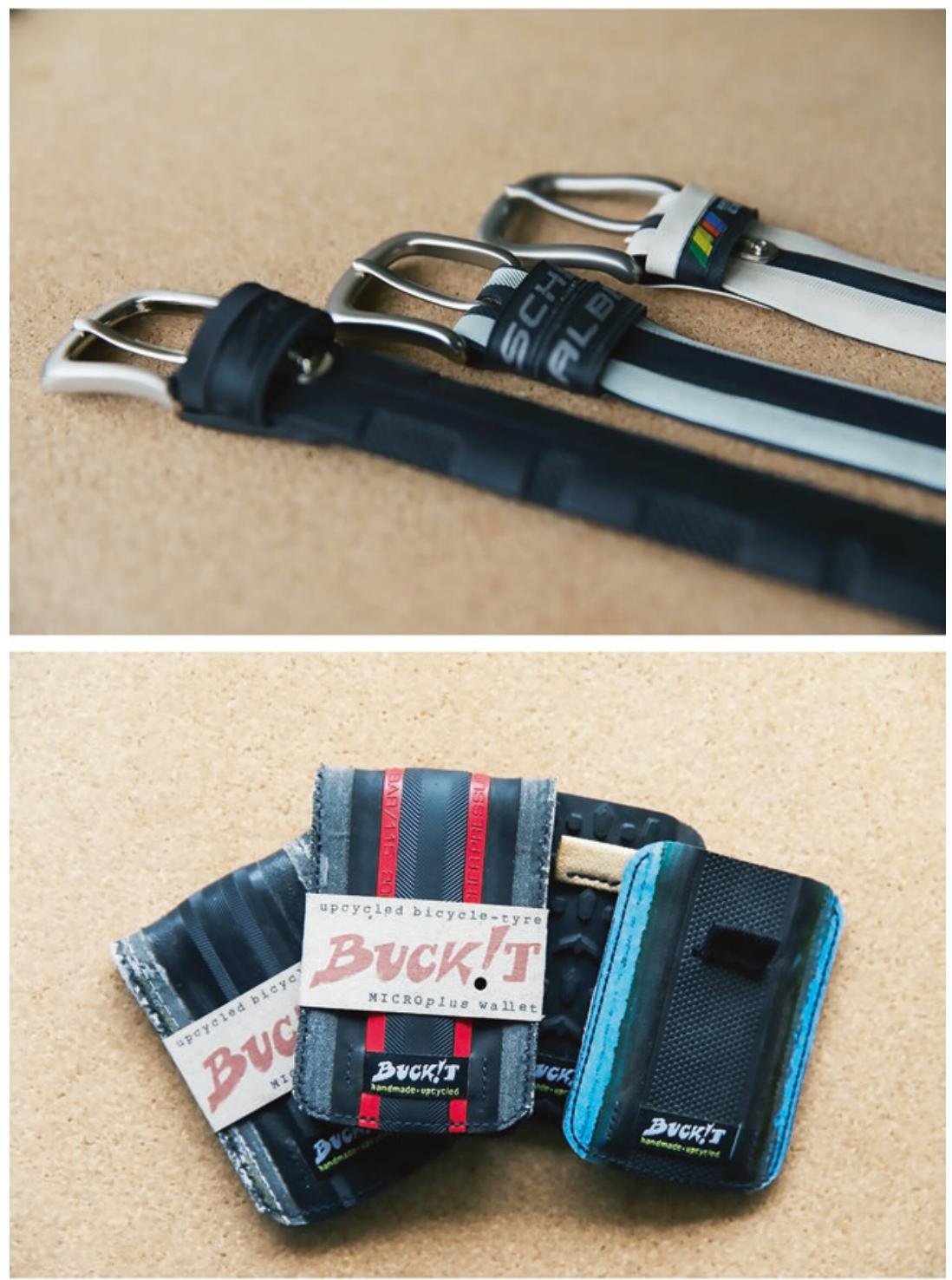

Figs. 7.1-7.4 (continued) 

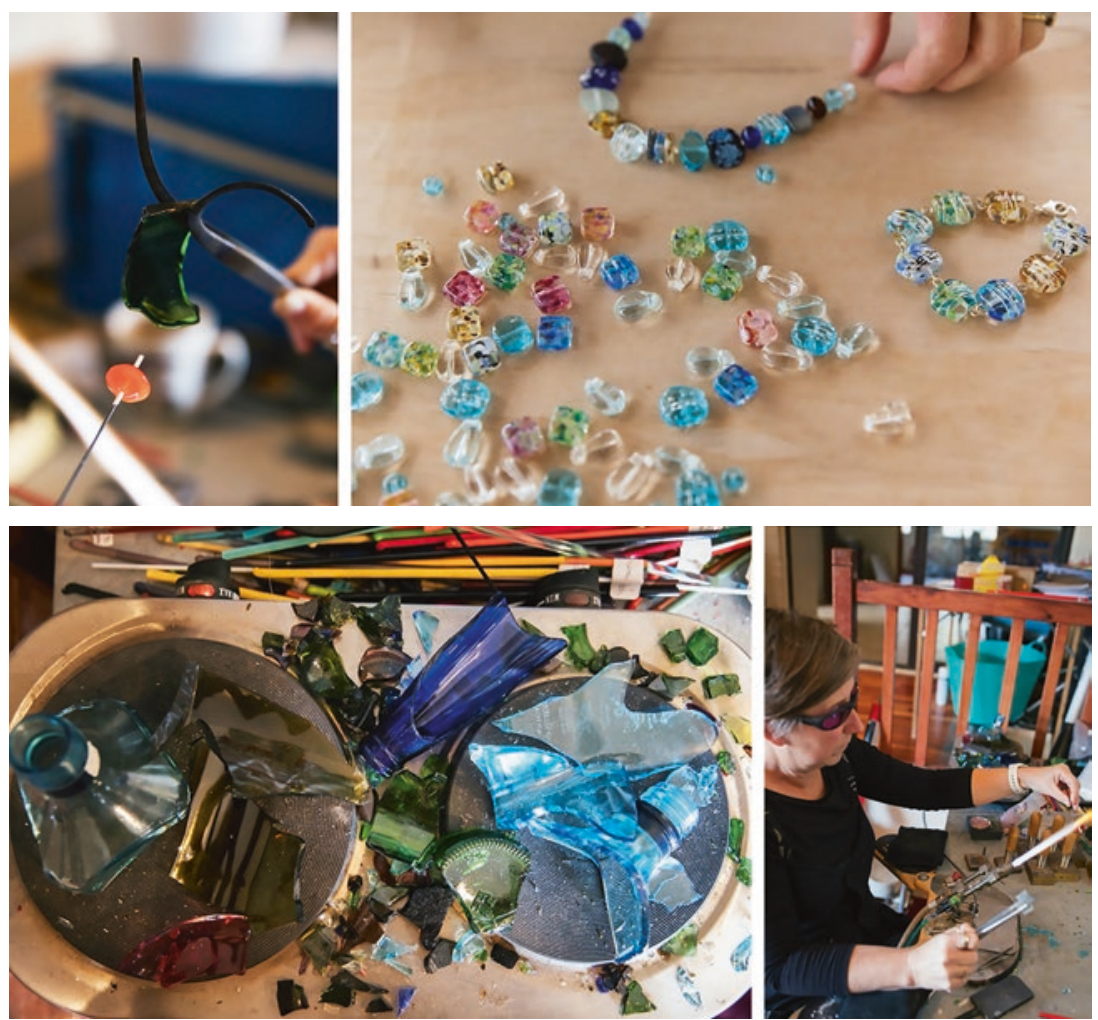

Figs. 7.5-7.8 Julie Frahm working recycled glass into glass beads. (Photographs: Rosina Possingham Photography)

\section{Why It's Important to Give Attention to This:}

\section{The Toxic Shadow Realities of Craft}

Despite the genuine best intentions of the makers, all the production and practices we have outlined remain bound up in complex negotiations and often easily critiqued environmental ethics. Again, do we really need all this stuff? It may be useful, therefore, to consider the handmade cultural 
economy as operating within a complex band of activity that Kate Soper (2004) has referred to as 'consumer citizenship' or 'alternative hedonism'. Even if it is not revolutionary in its own right, this activity points towards the possibilities of a better way of being (Sassatelli 2006, 2009). Soper argues for the importance of recasting the lifestyle changes necessary to facilitate a more sustainable way of life so they are not defined by their lack. But as we hope we have demonstrated here, to focus on the consumer side of design craft is to draw attention away from the deeper embeddedness of the craft economy within larger-scale systems of production and their impacts-good and bad. We need to look upstream as well as downstream.

Beyond and often even within many of the material practices we have outlined here, there remain shadow realities. Craft's localised making and selling happens within transnational circulation networks, which the emphasis on the local can too quickly obscure. The strategies of waste reuse outlined here become more noteworthy, even when undertaken on a micro-entrepreneurial level, when you locate individual makers as themselves consumers within global supply chains where, for example, most raw hides from Australian animals are sent to Germany or China for leather tanning and Australian merino wool is turned into fine fibre in Italy. Indeed, reusing existing coloured glass becomes an almost radical gesture in the face of recent events at one of the world's leading producers of art glass: Bullseye Glass Company in Portland, Oregon. In 2016, global supply chains for art glass were severely impacted by the voluntary shutting down of production following the initial finding of high lead levels in air emissions from the factory, which upon further inspection were joined by other irregularities. To quote from the company's own announcement regarding the issue:

Although Bullseye was operating within EPA [Environment Protection Authority] guidelines and its DEQ [Oregon's Department of Environmental Quality] air contaminate discharge permit, it voluntarily ceased all production of glasses containing cadmium and arsenic on February 4 when high levels of those elements were discovered in the surrounding area, and immediately took steps to limit emissions by beginning construction of furnace filtration systems. The following week it discontinued production of chromium glasses, shutting down more than $60 \%$ of its product lines. Oregon's governor, Kate Brown, further restricted production of lead glasses plus 
four additional metals that had never exceeded health benchmarks for ten days beginning on May 19, reducing the factory output to just $20 \%$ of its original product line. (Bullseye Glass Company 2016a)

The colours suspended from production at this time were those made with cadmium (bright yellows, oranges and reds) and chromium (greens) (Bullseye Glass Company 2016b). And as we have seen, for reasons similar to those in the Bullseye situation, Australian makers prefer German leather tanning, for although it represents far more 'craft miles', Europe, like the USA, is seen to have far stricter environmental and labour regulations than China and other lower-cost markets.

Beyond materials sourcing, actually working with these materials draws upon considerable resources, notably, electricity. To offset this, a number of the makers we spoke to who had some degree of control over their studio space have installed solar panels or sought to lease spaces where they were already present. Some warehouse making facilities require triplephase power, which allows them to install large solar systems. But the shadow realities of much making remain and haunt the practice of craftspeople and designer makers with a genuine desire to reduce their environmental footprint:

I mean, if there is an option to use a more environmentally friendly process or product or glue or whatever, then I'll try and find a way to use that. [ ... ] With this, so this bench, for example, the log bench, I use a glue which probably wouldn't get a green star rating but it's been tricky to try and find a replacement for that so that's an ongoing thing actually, trying to find a different glue solution for that product. (Scott van Tuil, furniture maker and designer, emerging maker, February 2016)

With regard to the environmental concerns, I don't think ceramics is terribly environmentally friendly. We use stuff that's dug up from the ground. We use oxides, which can be quite toxic. We use electricity. What I do is, you know, I try and be water wise in that I have rainwater tanks that I use for, that I collect water to use for a lot of my work. I try and minimise the amount of firing work that I do. I recycle all my clay. As you can see by my front garden, I'm a really keen gardener. [ ... ] I'm really into the whole idea of permaculture, so I've been giving some of my leftover clay to some in the permaculture group that I'm a member of, because they're using it to [improve] the soil here [which] is incredibly sandy, and you have to add clay to it to get it to grow, so a lot of my slops and things go on the garden. So, 
yeah, I mean I'd like to be able to fire with gas, but in an urban backyard it's kind of hard and expensive to get it all certified. (Stephanie Hammill, ceramics, established maker, November 2016)

Interestingly, Stephanie was one of the few ceramicists to question the sourcing of their materials. Some commented upon the use of electricity, but few on the source of their raw materials.

\section{Craft = Quality = 'Made TO LAST' /'MADE TO Hold Onto’' (and Be Repairable)}

Laura McCusker's contemporary furniture practice connects directly with John Ruskin's ethos evoked in the opening to this chapter: 'If we build, let us think that we build forever' (Pye 1995, 83), which advocates ideas of craftsmanship as representing quality, commitment and building to last. Laura and her partner make 'quality handmade, individually designed pieces' tailored to their clients' specific needs. Laura McCusker Furniture was established in 1996 under the flight path in Sydney's industrial inner west. They have since moved to Tasmania, where they now work in old farm complex in Hobart, next to a babbling brook and surrounded by heirloom fruit trees, with their main studio in an old apple packing shed. Arguably, they are thus also examples of design craft practitioners pursuing craft as part of a wider lifestyle downshifting choice, to be discussed further shortly.

Valuing materials as they generally do and in an attempt to have some control over their own resource security, craftspeople and often also their clients can tend to hoard materials, especially when an opportunity arises to secure any rare, unique or difficult-to-procure items. Rare native timbers are a case in point and may literally represent a windfall in the case of Huon Pine, as the live trees are now protected. Such raw material has value and significance to people in its own right, even before it is worked:

We had a client a few years ago who had these massive pieces of Huon Pine which he'd been carrying around from house to house to house over the last sort of 30 to 40 years, waiting to build his dream home. And he's finally finished his home out at Cambridge, really beautiful, simple and modest contemporary build and was now ready for the table to go with it. So they brought the Huon - they brought the timber to us. We made it into a table. We made it into a table. We delivered the table to them, put it in there-they 
had some Jansz on ice for us when we arrived there and we had a glass of champagne looking out over this incredible view in Cambridge. And it was just - it was really lovely. When you know that the timber's got a provenance like that, and you can feel comfortable that it's ethically sourced and wellseasoned, and you've got an opportunity to do something like that, it's pretty special. (Laura McCusker, furniture maker, established maker, February 2016)

To hold onto this timber until such a time as the owners are in a position to turn it into a functional part of their everyday lives is to see this material truly, as a 'gift' offered by the natural world (Bennett 2001). The journey of this gift from raw wood to table is but one stage of this relationship, which today can also be shared between maker and client via digital communication, reinforcing the bond.

Laura describes another table commission. In a practice not unique to furniture making, in the spirit of building to last and to keep, social media is employed to nurture a deep relationship with the object even before the person paying for it has it in their possession:

If we're building a piece of furniture for someone we hash tag it so they can follow it and they can sort of see, they have a catalogue at the end of the actual development of the project as it goes. And we use it like that and we've found that as someone-like there's a guy we made a table for in Sydney. He was showing the hashtag to all of his friends and all of these other people were getting onto Instagram and watching his table progress and getting really excited about this table. And even progress from the timber for that table, we were able to get from Kevin Perkins down in Franklin, who's a significant furniture maker in Australia. And he'd cut the timber down in October 1984, this blackwood tree. And so we were able to find this - and it's sequentially cut and stickered out so we were able to take a photograph of it in the shed, photograph on the back of the ute, coming here, and actually have from that stage all the way through to the end. And so when we delivered it, we sent it up there, the client phoned back and said that - we had some offcuts, about 300 from the end of the table-and he's asked us to make two stools for his two sons out of those timber so that it comes - the table has these matching — because of that history, because we were able to put it into context like that. And so there's that ownership of the piece before it even exists and the whole family are kind of excited about it. (Laura McCusker, furniture maker, established maker, February 2016) 
This connection with the material is in this way translated onto the quality, handmade table to come. Thus, in contemporary designer making, we can see further connections to Ruskin's notion of durability and to the more temporary (but nonetheless meaningful experience) of being able to work with it, as in Laura's case. This is a piece of furniture to be kept and valued, not replaced when fashions change.

Indeed, while it is owned by a particular person, the item animates affective relationships of care that now extend beyond the owner's proprietorial interest. Laura's sense of care to the item does not end when it leaves her studio:

So we'll give people a call a year after and say, "Does it need a refinish or does it need a touch up?" or whatever. But, because we do work mainly locally, people know where we are and if they've got any issues or if theywe get a lot of people who come back for other bits and pieces. We keep in contact and there's not much [that can go wrong], with this type of furniture that we're making, they're pretty bulletproof. There's not much that you can do that can't be repaired. And we say that. [Also] they might change and grow out of how-I mean obviously if you buy a table that's a 16-seater, at some point in your life you might downsize and move to a smaller house but the table doesn't get thrown out, it gets handed on. And you might come to us as a young couple that's living in a share accommodation or in rental accommodation and you might have something really small and at some point you get to a bigger house and you need something bigger. But that table still gets repurposed as a desk in an office space or something, and we say to them we can always help if they do need a hand moving it or if it needs to be refinished or what have you, all that sort of stuff. That's part of when you make a connection with a local maker you can actually do that. It's an ongoing relationship. (Laura McCusker, furniture maker, established maker, February 2016)

With the near global ubiquity of Ikea and the kinds of homewares once the sole province of design stores available at cheap prices in discount retail stores, high-turnover, non-recyclable fashion is no longer the sole preserve of the global clothing industry. Handmade items, especially crafts-built furniture, tend not to be cheap (up front at least); they reflect both the quality of the materials and the skill involved in their making. However, a return to thinking of furniture and homewares as investments with which we may even have a lifelong relationship clearly has a role to play in imagining sustainable climate futures. Furniture may be an obvious 
candidate for such relationships, but makers of even what we might consider higher-turnover production (rather than gallery work) items sought to locate their practice within a setting of concern for sustainability marked by longevity:

We use every element of the canvas. We don't have wastage. We have a couple of scraps and usually the girls across the road come and grab those and we will have small cuttings but we make all these pieces that generally get smaller and smaller so we can utilise every element. I think probably we do try and keep all of our production here in Adelaide so it is focused on showing people that you don't have to make a cheap product and $[\ldots]$ people will value a well-made product that might be more expensive. We probably have a lot more competition in the market at the moment of home mums making bags that resemble ours and they will sell them for maybe a quarter of the price to half the price, but the difference I would hope is manufacturing also the quality of the products that we use, and the level of quality that our product stays at consistently and the quality of our painting-that we have depth and we're constantly improving our processes and practices. [...] It's more about the ethics that we have in our product as such, and that it's something that is not fast fashion that you have it forever and it's maybe they are buying a very bespoke product that is not just a throw away item. (Tiff Manuell, handmade clutches, bags and accessories, established maker, September 2017)

Making to last and to be kept links strongly too with the capacity to be able to maintain the item as part of its ongoing durability.

Repair has a long history in and with craft:

Not only tools like lathes, drill presses, and looms but also power sources like steam engines, water mills, and blast furnaces: all were made using longestablished crafts of blacksmithing, carpentry, and masonry. Keeping production going was also a job for artisans. In a sense the repair of these large-scale machines and even smaller bench tools was another imitative craft, in that the goal was to restore the tool to its original, or at least its working condition. This is a particularly elusive topic for the historian, because repair was (even more than other aspects of industrial craft) taken for granted in its own day. This is a subspecies of a more general problem in craft history, well described by Thomas Schlereth twenty years ago but that has not changed much since: 'Often in the fetish we make of finished things or the hero worship we accord individual artisans, we forget that in preindustrial times craftsmen often spent as much (or more) time repairing rather than making from scratch.' (Adamson 2013, 147) 
Today, being able to repair items in a contemporary world of too much stuff is emerging as a significant material battleground. Writing about the now iconic 2011 Power of Making exhibition at the Victoria and Albert Museum, leading British craft writer Tanya Harrod acknowledges in a 2011 article in the Times Literary Supplement that it:

challenges the notion that manufacture has become a thing of the past in Europe and North America. Most of us assume, correctly, that the majority of our goods are made in factories in the Far East, probably situated in the Pearl River Delta of Southern China. And we are equally conscious that we no longer understand the internal workings of the products we buy and cannot fix them. There is little point in looking under the bonnet of a car these days. Cars come with their own software and a mechanic is more likely to tap at a laptop than use a monkey wrench. 'Power of Making' sets out to rectify this sense of helplessness by suggesting that we need not remain passive consumers. We can combine literacy and handwork. (Harrod 2015a, 20)

Whereas the right to repair movement is strongly associated with breaking into the white (black) box of digital technology, craft practices of repair-'make do and mend'-have long been essential thrifty survival skills which need to be, and are being, reinvigorated. Furthermore, increasingly, among those in a socio-economic position to do so, its aesthetics are being valued as a marker of cultural capital and not just economic disadvantage. The wider revival of artisanal making practices offers a fertile ground within which reworking and repair practices can be reimagined for the current age.

\section{Craft as Part of a Lifestyle Downshifting Choice}

For some of our participants, another less obvious way in which making is tied up with environmental awareness is the embrace of this form of income generation as part of a much larger approach to living all aspects of their life in a manner that reduces consumption and thus their personal environmental footprint. As something of a 'downshifted cultural economy' (although perhaps not a 'drop out' one), self-employment continues to attract people precisely on account of the greater freedom it grants individuals 'to set the level of the necessary labor payment and the boundary between necessary and surplus labor' (Gibson-Graham 2006, 89). As outlined in Chap. 2's discussion of participant motivations, a number of 
the craftspeople and designer makers we spoke with were deliberately pursuing making as part of a wider commitment to living what they saw as a more sustainable good life, one that may well lead to fewer financial rewards, but this is more than balanced through more time spent doing work that they love, as well as being more available for family and community.

With craft work often pursued alongside a larger strategy of personal or family downshifting, it also logically intersects with wider 'slow living' movements that are gaining traction in the Global North. Although many people, even in Australia, may feel they are not in a financial or personal position to be able to make this change, for many who have, their lowimpact living works to mitigate the need for medium-to-high incomes. Many respondents who work from home note they are free from having to purchase a work wardrobe. They also value that they are not contributing to road congestion and private car use in the form of daily commuting. In this contemporary incarnation of craft we can see connections to a longer history of 'back to basics' lifestyles, including the 1960s and 1970s-style craft reuse and sustainable/organic living, which also sought to bypass accelerated cultures and practices of consumption. Such lifestyle approaches offer valuable insights into how-in a climate crisis future-we can reimagine aesthetics in terms of what we are gaining, rather than what we are losing, when making the lifestyle and production changes that are essential to arrest climate change.

\section{Low Carbon Futures and Digital Tools}

A couple of makers we interviewed spoke of how working with digital cutters or digital printing allowed them to map out designs onto raw materials very tightly, far more than had previously been possible, leading to far less wastage after the desired shapes had been cut out. For example, Robyn ('Boo') McLean from Northern Territory-based Bippidii Boppidii designs and arranges her custom fabric designs for various personal and homewares accessories on a computer before sending them off for digital printing. This means, firstly, that no dye is wasted on elements of the fabric that are not to be used (Fletcher 2014, 66) and, secondly, that as much of the fabric as possible can be used up to produce the various material elements (including product labels), ensuring minimal offcuts: 
The way I print reduces waste. [ ... ] People are always asking me for scraps [but] I don't have any, because I make all these fridge magnets. They're the alphabets and I also do them with pictures on them, and so any bit on a piece of fabric that's too small to fit a sunglasses case or something, I fill it up with those. So, out of a metre I have these little tiny scraps. (Robyn ('Boo') McLean, Bippidii Boppidii, established maker, July 2017)

Other respondents reported similar outcomes from using computer numerical control routers and laser cutters to minimise waste when cutting out wooden component parts.

Commissions are a key part of many makers' sales. In addition to designing to order, another opportunity found among our participants was making to order, which is enabled by the on-demand production capacities of digital tools. Uploading designs to platforms such as Etsy that can be made only on demand via online $3 \mathrm{D}$ printing services such as Shapeways (https://www.shapeways.com/) enables new kinds of designer maker practices to emerge that reduce waste by producing an item only when there is demand for it. However, this practice has had limited takeup as yet in Australia, perhaps partly because of the still ambiguous market response to craft or designer maker items produced through additive manufacturing (this is discussed in more detail in Chap. 5).

\section{Circular Economies of Craft}

Finally, more attention should be given to the possibilities around circular economies of craft, such as Seljak Brand's recycled wool blankets, which can be returned to them for re-milling once they reach the end of their useable life (https://www.seljakbrand.com.au/). The kinds of waste minimisation practices detailed in this chapter are incredibly worthy and valuable, but the ongoing relationship to the object and its materials, even after its current use is exhausted, was beyond the scope of many of the makers we spoke to. There were some exceptions, such as Laura McCusker's repair and reworking of furniture for customers well after the initial point of sale, and Clare Poppi's reworking of jewellery. However as sustainable fashion researcher Kate Fletcher has written, the focus on materials is 'often the place where many sustainability conversations begin' and unfortunately end $(2016,170)$. In the context of fibre and fashion, she challenges makers and consumers to think beyond materials to the whole life cycle of goods (Fletcher 2014, 8). For this reason, the circular economy 
remains an important and currently under-explored part of the contemporary craft and designer maker economy in Australia, where most makers are just trying to make enough to get by and do not always have the capacity to take such a long-term view.

The craft sector is a big and diverse space comprising lots of different communities of practice. Some craft makers do abundance well, but the design craft market is also contributing to the problem of abundance, of excess. In the 1990s, Whiteley (1997) asserted in his book Design for Society that the increasingly high profile of the 'green consumer' in the 1980s was just the exploitation of a consumer niche. Because we did not specifically interview consumers as part of this project, the place of craft within ethical consumption practices is something we cannot speak to in any depth. But while it cannot be said that 'greenwashing'-promoting something as greener than it may actually be-does not exist in this space (for environmental awareness as a marketing strategy does play well with many craft and design consumers), what is clearly also present in our interviews is the deeper connection to craft's history of respecting materials and processes, of being attentive to them. As we have seen, we need to attend critically not only to the post-making circulation of craft objects and challenge the value of so much 'stuff' but also to the input production chains within which craft operates. Harrod, writing in a 2013 article published in the Philosophical Transactions of the Royal Society A: Mathematical, Physical and Engineering Sciences, observes:

In a full world that means making anything at all is a responsibility. In the context of providing material services with less material production, visionary rather than practical responses to materials and processes should not be ignored. The activities of artists and experimental designers can offer alternative value systems and new ways of approaching sustainability and material efficiency. (Harrod 2015b, 338)

Many of the makers we encountered in this study are clearly seeking to contribute to this endeavour in their own ways. Scale remains a significant challenge though, and we should also be aware of the need to challenge the idea of the cultural economy as being somehow inherently progressive (Gill 2014), given the complicity of creativity within promotional economies and discourses of endless consumption as an ideal state of being. Makers, too, need to be part of challenging the growth narrative, and, as we have seen, many are very much aware of their environmental impacts. 
The first two Western arts and crafts peaks both failed to translate into wider change and relevance because of the limits to scaling-up craft practice. Scaling from an individual to a larger-scale practice remains a key challenge for craft, having important affordability constraints for most people. But makers do have a pivotal role to play in a post-climate change understanding of the impacts and thus the potential preciousness of all materials, especially on behalf of the consumer, for whom the finished object may be all too often the prime focus. As Jane Bennett (2001) observes:

For me, the issue is not whether to live with commodities but how to participate in commodity culture, for there is no vision of capitalist or noncapitalist economy today that does not include some role for the commodity form. The pertinent questions become how to reform commodity culture to render it more just and ecologically sustainable and how to extract the ethical potential within commodity culture. (Bennett, 113)

In terms of crafts and designer making, the opportunity remains in the skill sets, implicit knowledges, and deep understandings of materials and process that craftspeople can bring to the challenge of thinking through the properties and affordances of materials within wider systems. This includes the capacity to tinker, to play, to repair, to reuse-for 'waste' is always on the move, always 'becoming'. More and better ways need to be found for these knowledges to be brought into dialogue with, adopted by or give rise to larger scales of production.

\section{REFERENCES}

Adamson, G. (2013). The invention of craft. London: Bloomsbury.

Bennett, J. (2001). The enchantment of modern life: Attachments, crossings, and ethics. Princeton and Oxford: Princeton University Press.

Bennett, J. (2010). Vibrant matter: A political ecology of things. Durham and London: Duke University Press.

Bullseye Glass Company. (2016a). Bullseye proposes new production limits to DEQ. News release 25 May. Retrieved from http://www.bullseyeglass.com/ news/bullseye-proposes-new-production-limits-to-deq.html.

Bullseye Glass Company. (2016b). The road ahead: An update for our customers. News release 18 May. Retrieved from http://www.bullseyeglass.com/news/ the-road-ahead-an-update-for-our-customers.html. 
Fletcher, K. (2014). Sustainable fashion and textiles (2nd ed.). London and New York: Routledge (Earthscan).

Fletcher, K. (2016). Craft of use. London and New York: Routledge.

Gibson-Graham, J. K. (2006). A postcapitalist politics. Minneapolis, MN: University of Minnesota Press.

Gill, R. (2014). Unspeakable inequalities: Post feminism, entrepreneurial subjectivity, and the repudiation of sexism among cultural workers. Social Politics: International Studies in Gender, State and Society, 21(4), 509-528.

Harrod, T. (2015a). The power of making. In T. Harrod, The real thing: Essays on making in the modern world (pp. 20-22). London: Hyphen Press.

Harrod, T. (2015b). 'Visionary rather than practical': Craft, art, and material efficiency. In T. Harrod, The real thing: Essays on making in the modern world (pp. 327-340). London: Hyphen Press.

Hydrowood. (n.d.). Our story. Retrieved January 20, 2020, fromhttp://www. hydrowood.com.au/our-story-2.

Pye, D. (1995). The nature and art of workmanship. London and Cambridge: The Herbert Press and Cambridge University Press.

Sassatelli, R. (2006). Virtue, responsibility and consumer choice: Framing critical consumerism. In J. Brewer \& F. Trentmann (Eds.), Consuming cultures, global perspectives: Historical trajectories, transnational exchanges (pp. 219-250). Oxford and New York: Berg.

Sassatelli, R. (2009). Representing consumers: Contesting claims and agendas. In K. Soper, M. Ryle, \& L. Thomas (Eds.), The politics and pleasures of consuming differently (pp. 25-42). Basingstoke and New York: Palgrave Macmillan.

Schwarz, M., \& Yair, K. (2010). Making value: Craft and the economic and social contribution of makers. London: Crafts Council.

Soper, K. (2004). Rethinking the 'good life': The consumer as citizen. Capitalism, Nature, Socialism, 15(3), 111-116.

Whiteley, N. (1997). Design for society. Chicago and London: The University of Chicago Press. 
Open Access This chapter is licensed under the terms of the Creative Commons Attribution 4.0 International License (http://creativecommons.org/licenses/ by $/ 4.0 /$ ), which permits use, sharing, adaptation, distribution and reproduction in any medium or format, as long as you give appropriate credit to the original author(s) and the source, provide a link to the Creative Commons licence and indicate if changes were made.

The images or other third party material in this chapter are included in the chapter's Creative Commons licence, unless indicated otherwise in a credit line to the material. If material is not included in the chapter's Creative Commons licence and your intended use is not permitted by statutory regulation or exceeds the permitted use, you will need to obtain permission directly from the copyright holder.

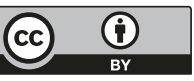

